\title{
Thrombolysis of a modified Blalock-Taussig shunt with recombinant tissue plasminogen activator in a newborn infant with pulmonary atresia and ventricular septal defect
}

\author{
M Ries, H Singer, $M$ Hofbeck
}

\begin{abstract}
A 10 day old infant with pulmonary atresia, ventricular septal defect, and collateral pulmonary blood supply through a left sided ductus arteriosus developed complete shunt thrombosis four days after the creation of a modified BlalockTaussig shunt. Recombinant tissue plasminogen activator was given locally into the proximal end of the shunt as two bolus injections of $0.1 \mathrm{mg} / \mathrm{kg}$ and two bolus injections of $0.2 \mathrm{mg} / \mathrm{kg}$ over $10 \mathrm{~min}$ utes, followed by a continuous infusion of $1.4 \mathrm{mg} / \mathrm{kg} / \mathrm{day}$ for 16 hours and 0.7 $\mathrm{mg} / \mathrm{kg} /$ day for 18 hours with systemic low dose heparin $5 \mathrm{IU} / \mathrm{kg} / \mathrm{h}$. This resulted in complete clot dissolution and reperfusion without haemorrhagic complications and without laboratory signs of systemic fibrinolytic activation.
\end{abstract}

(Br Heart $\mathcal{~ f ~ 1 9 9 4 ; 7 2 : 2 0 1 - 2 0 2 ) ~}$

Recombinant tissue plasminogen activator is an effective thrombolytic agent that preferentially activates fibrin bound plasminogen and has a shorter plasma half life than streptokinase and urokinase. ${ }^{1-3}$ Data on the use and the dose regimens of recombinant tissue plasminogen activator for thrombolysis in children are few..$^{4-6}$ We report the successful use of recombinant tissue plasminogen activator for the treatment of a thrombosed modified Blalock-Taussig shunt in a 10 day old infant.

\section{Case report}

A male infant was born at term (birth weight $3560 \mathrm{~g}$ ) after an uneventful pregnancy. The child was referred to our hospital on the fourth day of life because of central cyanosis. The results of echocardiography and cardiac catheterisation showed pulmonary atresia and ventricular septal defect. The right and left pulmonary arteries were confluent without a main pulmonary trunk and the collateral lung perfusion was provided by a left sided ductus arteriosus. Intravenous prostaglandin was accompanied by an immediate improvement in arterial oxygenation. On the sixth day of life a modified right Blalock-Taussig shunt procedure was performed using a $4.0 \mathrm{~mm}$ Goretex graft. The ductus arteriosus was not ligated. Four days later the child developed progressive cyanosis. The results of echocardiography and cardiac catheterisation showed a completely thrombosed Blalock-Taussig shunt (fig 1).

We started fibrinolytic treatment with two local applications of $0.1 \mathrm{mg} / \mathrm{kg}$ and two doses of $0.2 \mathrm{mg} / \mathrm{kg}$ recombinant tissue plasminogen activator as slow bolus injections over 10 minutes into the proximal end of the shunt. This resulted in partial lysis of the clot (fig 2). The arterial catheter was left in place in the subclavian artery. We began treatment with a continuous infusion of recombinant tissue plasminogen activator $1.4 \mathrm{mg} / \mathrm{kg} / \mathrm{h}$ for 16 hours and $0.7 \mathrm{mg} / \mathrm{kg} / \mathrm{h}$ for 18 hours into the shunt with systemic low dose heparin (5 $\mathrm{IU} / \mathrm{kg} / \mathrm{h})$. With this regimen the clot dissolved completely and the infant's condition improved without the development of haemorrhagic complications (fig 3 ).

To avoid reocclusion after thrombolysis, infusion of heparin was increased to 20 $\mathrm{IU} / \mathrm{kg} / \mathrm{h}$ for five days and then reduced to 10 $\mathrm{IU} / \mathrm{kg} / \mathrm{h}$ for another five days.

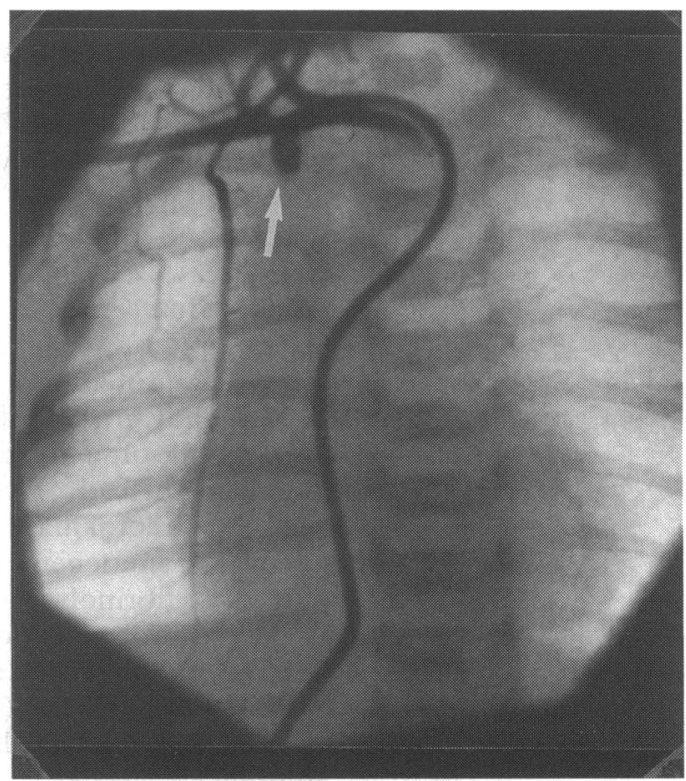

Figure 1 Selective injection into the truncus brachiocephalicus. Note the completely thrombosed modified Blalock-Taussig shunt (arrow). The catheter is placed into the truncus brachiocephalicus through the femoral vein, right ventricle, ventricular septal defect, and ascending aorta. 
Figure 2 Selective angiogram in the proximal end of the shunt after two bolus injections of $0 \cdot 1$ $\mathrm{mg} / \mathrm{kg}$ and two of $0 \cdot 2$ mg/kg recombinant tissue plasminogen activator. Angiogram shows partial reperfusion of the shunt; the catheter is inserted into the right brachial artery.

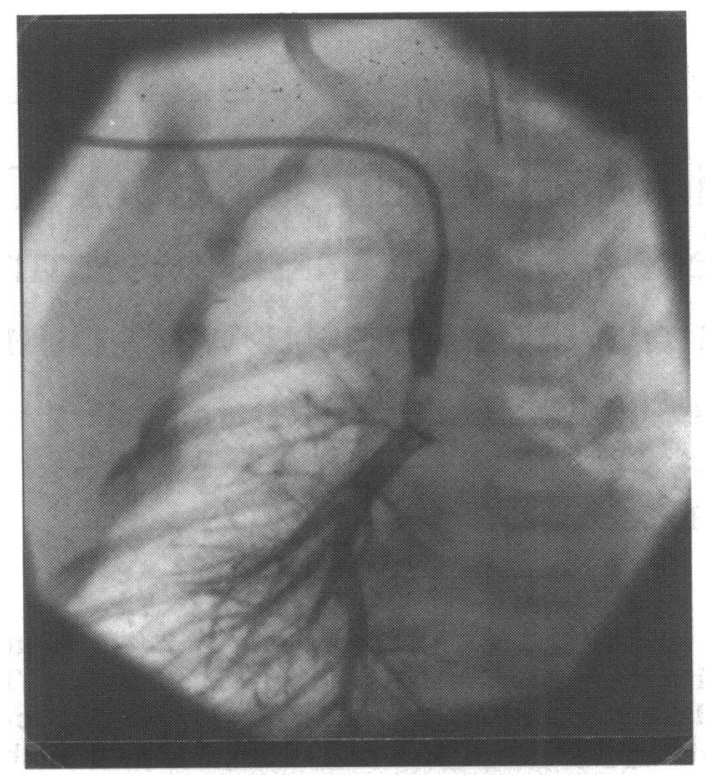

Figure 3 Angiogram of the right subclavian artery after continuous infusion of recombinant tissue plasminogen activator $1.4 \mathrm{mg} / \mathrm{kg} /$ day for 16 hours and

$0.7 \mathrm{mg} / \mathrm{kg} /$ day for 18 hours accompanied by systemic low dose heparin (5 IU/kg/h). Angiogram shows complete clot dissolution and reperfusion of the modified BlalockTaussig shunt.

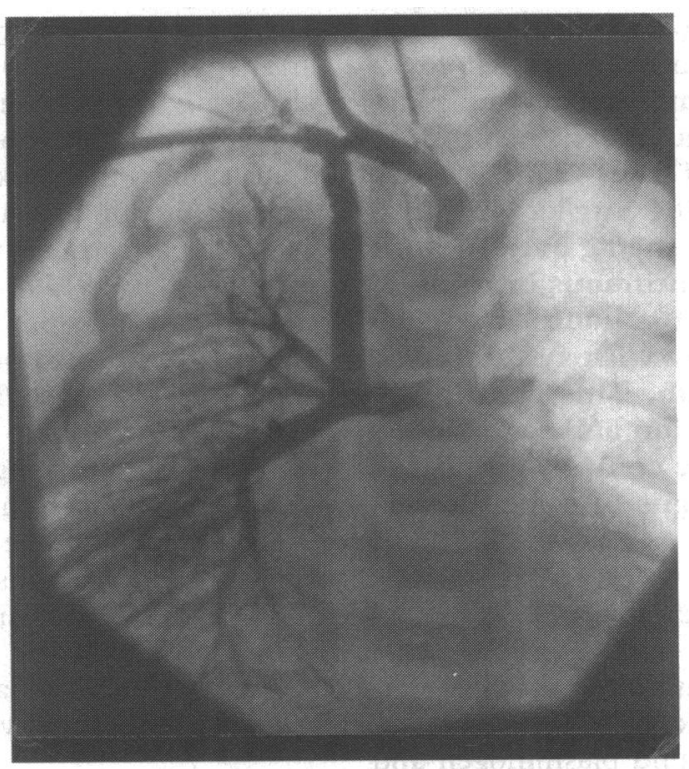

When the child was 6 weeks old, his ductus arteriosus had almost completely closed and the modified Blalock-Taussig shunt was functioning well, as shown by colour Doppler ultrasonography.

\section{Discussion}

Tissue plasminogen activator is a naturally occurring protein and a thrombolytic agent. It has the advantages of binding specifically to fibrin and of activating fibrin bound plasminogen instead of circulating plasminogen, as does streptokinase and urokinase. ${ }^{13}$ Thus tissue plasminogen activator induces clot selective fibrinolysis without producing a widespread proteolytic state. ${ }^{7}$ In addition, the plasma half lives of streptokinase (23 minutes) and urokinase (16 minutes) are longer than that of tissue plasminogen activator ( 5 minutes). ${ }^{28}$
To our knowledge, there are only a few reports on the use of recombinant tissue plasminogen activator for treating vascular and intracardiac thrombosis in children. ${ }^{4-6}$ Therefore a recommended regimen for dosage in children has not yet been established. The decision to use thrombolysis in our patient in preference to performing a new aortopulmonary shunt was based on the risk of progressive thrombosis into the right pulmonary artery and of stenosis at the site of the new shunt. We are not aware of other reports on thrombolysis of a modified Blalock-Taussig shunt in a newborn baby.

During thrombolysis with our dose regimen we saw no haemorrhagic complications and no decrease in fibrinogen or plasminogen concentrations as a sign of systemic fibrinolytic activation by recombinant tissue plasminogen activator. Previous studies have not shown a correlation between the presence of markers of coagulation and the occurrence of haemorrhagic complications. ${ }^{9-11}$ Therefore intensive clinical monitoring is necessary during thrombolysis.

In conclusion, thrombolysis with local application of recombinant tissue plasminogen activator at our dose regimen was safe and effective. The use of recombinant tissue plasminogen activator in thrombotic disease should be investigated further to establish dosage guidelines for local and systemic applications, complications, contraindications, and efficacy compared with streptokinase and urokinase in children.

1 Hoylaerts M, Rijken DC, Lijnen HR, Collen D. Kinetics of the activation of plasminogen by human tissue plasminogen activator. F Biol Chem 1982;257:2912-9.

2 Marder VJ, Sherry S. Thrombolytic therapy: current status. Parts I and II. N Engl fै Med 1988;318:1512-20, 1585-94.

3 Thorsen S, Glas-Greenwalt P, Astrup T. Differences in the binding to fibrin of urokinase and tissue plasminogen activator. Thromb Haemost 1972;28:65-74.

4 Asante-Korang A Sreeram N, McKay R, Arnold R Thrombolysis with tissue-type plasminogen activator following cardiac surgery in children. Int $f$ Cardiol 1992;35:317-22.

5 Levy M, Benson LN, Burrows PE, Bentur Y, Strong DK, Smith J, et al. Tissue plasminogen activator for the treatSmith J, et al. Tissue plasminogen activator for the treatment of thromboembolism

6 Nowak-Gött U, Schwabe D, Schneider W, Schlösser R Kreuz W. Thrombolysis with recombinant tissue-type Kreuz W. Thrombolysis with recombinant tissue-type plasminogen activator in renal

7 Runge MS, Quertermous T, Haber E. Plasminogen activators. The old and the new. Circulation 1989;79: 217-24.

8 Crabbe SJ, Cloninger CC. Tissue plasminogen activator a new thrombolytic agent. Clin Pharm 1987;6:373-86.

9 Mueller HS, Rao AK, Forman SA. Thrombolysis in myocardial infarction (TIMI): comparative studies of coronary reperfusion and systemic fibrinolysis with two forms of recombinant tissue-type plasminogen activator. 7 Am Coll Cardiol 1987;10:479-90.

10 Naylor CD, Armstrong PW. Guidelines for the use of intravenous thrombolytic agents in acute myocardial infarction. Can Med Assoc 7 1989;140:1289-99.

11 Ries M, Singer H, Hofbeck M, Klinge J, Wild F, Vogel P. Systemic and local thrombolytic therapy with rt-PA (Actilyse) in children with congenital heart disease, Monatsschr Kinderheilkd 1994;142:205-8. 